\title{
Information from teachers on viral hepatitis transmission and prevention in Brazil
}

\author{
Rosangela Gaze, MD, MPh, (1) Diana Maul de C arvalho, MD, DSC, ${ }^{(2)}$ \\ Luiz Fernando Rangel-Tura, MD, DSC. ${ }^{(2)}$
}

\begin{abstract}
Gaze R, Maul de Carvalho D, Rangel-Tura LF. Information from teachers on viral hepatitis transmission and prevention in Brazil. Salud Publica Mex 2003;45:245-251. The English version of this paper is available too at: http://www.insp.mx/salud/index.html
\end{abstract}

\begin{abstract}
A bstract
Objective To assess school teachers' level of knowledge on prevention of viral hepatitis (VH). Material and Methods A cross-sectional study was conducted in three cities of Brazil, from August to N ovember of 1999.The sample was composed of 360 subjects: 334 women and 26 men, $81(22.5 \%)$ from Belém, 123 (34.2\%) from $\mathrm{N}$ atal and 156 (43.3\%) from Rio de Janeiro.C ultural differences in knowledge were identified using a questionnaire to classify, according to semantic content, categories of transmission and preventive practices. Responses were scored as right or wrong. Data were tabulated and analyzed using EPIIN FO 6.04 and open answers were classified according to semantic content. Comparison of the answer frequencies between cities was done through the chi-square test. Results Transmission category (TC) ( $n=837$ answers) and prevention category (PC) (n=771 answers) "food-and waterborne" transmission items were the most frequently mentioned (40\%). For TC, "food-and waterborne" answers were followed by "bloodborne" (16\%), "inadequate knowledge" (9\%), "possible causes of hepatic disease" (9\%), and "sexual transmission" (7\%) answers. For PC items, "food-and waterborne" answers were followed by "general aspects of prevention" $(13 \%)$, "immunization" (9\%), "quality of health services" (8\%) and "sexual prevention" (5\%) items. "Right" scores for transmission mechanisms and prevention practices varied from zero to $80 \%$. Conclusions Study findings suggest that investments should be made to disseminate appropriate know ledge onVH prevention, mainly addressing sexual transmission and intravenous drug use. The English version of this paper is available too at: http://www.insp.mx/salud/ index.html
\end{abstract}

Key words: hepatitis, viral, human; aw arenes; prevention practices; Brazil

\author{
Gaze R, Maul de Carvalho D, Rangel-Tura LF. \\ Información de los maestros sobre la transmisión \\ y la prevención de las hepatitis virales en el Brasil. \\ Salud Publica Mex 2003;45:245-251. \\ El texto completo en inglés de este artículo también \\ está disponible en: http://www.insp.mx/salud/index.html
}

\section{Resumen}

Objetivo. Evaluar los conocimientos y prácticas de profesores escolares en la prevención de hepatitis viral. Material y métodos. Se llevó a cabo un estudio transversal en tres ciudades de Brasil, de agosto a noviembre de 1999. La muestra estuvo constituida por 360 sujetos: 334 mujeres y 26 hombres, $81(22.5 \%)$ de Belém, $123(34.2 \%)$ de $\mathrm{N}$ ataly $156(43.3 \%)$ de Río de Janeiro. Se determinaron diferencias culturales en cuanto a conocimientos, prácticas y actitudes. Se utilizó un cuestionario clasificado según su contenido semántico en catego rías de transmisión y prácticas preventivas; las respuestas se evaluaron como "errores" y "aciertos". Los datos se tabularon y analizaron usando EPIIN FO 6.4 , y las respuestas abiertas se clasificaron de acuerdo con el contenido semántico. La comparación de las frecuencias de las respuestas entre las ciudades se hizo mediante ji cuadrada. Resultados En 837 respuestas en la catego ría transmisión y 771 en prevención, la comida y el agua fueron las más frecuentemente citadas (40\%). En transmisión, las respuestas subsecuentes fueron, en orden de frecuencia: transfusión de sangre (16\%), conocimiento inadecuado (9\%), causas posibles de enfermedades hepáticas (9\%) y transmisión sexual (7\%). En prevención, las respuestas subsecuentes fueron, en orden de frecuencia: aspectos generales de prevención (13\%), inmunización (9\%), calidad de los servicios de salud (8\%) y prevención sexual (5\%). El número de "aciertos" sobre mecanismos de transmisión y prácticas de prevención varió entre 0 y $80 \%$. Conclusiones. Los resultados sugieren que se debe invertir más en la difusión de conocimientos sobre hepatitis viral, su transmisión sexual y por el uso de drogas inyectables. El texto completo en inglés de este artículo también está disponible en: http:// www.insp.mx/salud/index.html

Palabras clave: hepatitis viral; conocimiento; prácticas preventivas; Brasil

(1) Rio de Janeiro Federal University Public Health N ucleus; Rio de Janeiro State Ministry of Health and Brazil's Ministry of Health, Brazil.

(2) Preventive Medicine D epartment and Rio de Janeiro Federal University Public Health N ucleus, Brazil.

Received on: June 20,2002 • Accepted on: February 26,2003

Address reprint requests to: Rosangela Gaze. R. Teodoro da Silva, 751 ap. 504. Bloco 02.Vila Isabel. Rio de Janeiro. RJ. Brasil. CEP: 20560-000. E-mail: rgaze@ nesc.ufr..br 
A though epidemiologic surveillance has long recognized viral hepatitis (VH) as a serious public health problem in Brazil, ${ }^{1}$ information on this subject is not widely disseminated. Due to the frequency of asymptomatic infections, the population largely ignores hepatitis as a serious disease.

It is known that the prevalence of hepatitis A virus (HAV) infection in people over 20 years of age can reach over $90 \%$ in some areas. ${ }^{2-4}$ Hepatitis B virus (HBV) infection -which affects 300 million chronically infected people worldwide- can reach a prevalence of $10 \%$ among blood donors ${ }^{5}$ in southern and southeast states of Brazil, and values above $80 \%$ in the western area of the Amazon basin. ${ }^{6,7}$ Even more alarming is the finding of prevalences of HBV infection -a sexually transmitted disease- around 9\% among adolescents. ${ }^{8}$ Hepatitis delta virus (HDV) co-infection or superinfection -which accelerates and worsens the course of HBV infection, has been found in the western Amazon, where up to $66.7 \%$ of the HBV infected can also have HDV. ${ }^{9}$ About $70 \%$ to $80 \%$ of HBV and HDV chronically infected persons develop cirrhosis, compared with $10 \%$ to $15 \%$ of the HBV-only affected people. ${ }^{10}$ There are about 170 million people chronically infected with the hepatitis $\mathrm{C}$ virus (HCV) in the world and every year 3 to 4 million new infections appear. ${ }^{11}$ Brazil presents prevalence estimates between $0.6 \%$ and $5.9 \%$ in blood donors, with values of $2.6 \%$ in Rio de Janeiro. ${ }^{12}$ A $69.5 \%$ prevalence has been reported in intravenous drug addicts. ${ }^{13}$ Even though it is the leading cause of chronic liver disease (85\%) in those infected and currently is the largest cause of hepatic transplant, it took more than 10 years to recognize the impact of HBV infection, perhaps because of its slow clinical evolution. ${ }^{10}$ Dissemination of HAV outbreaks and the increase of the burden of the disease with the change of the mean age of incidence, contribute to the rise of the indirect costs from work absenteeism and of medical care costs. ${ }^{14}$ Additionally, the high cost and the low effectiveness of treatment for chronic cases of hepatitis B and C emphasize the importance of making the population aware of the need for preventive practices. The lay public's knowledge of this problem has been shown to be insufficient. ${ }^{15}$ The effectiveness of the actions for disease prevention and control depends on the ready access to medical resources and on the behavior of the public in relation to the proposed preventive measures. The demand for vaccines, use of condoms, access to proper drinking water, quality blood products, and sterile medical and dentistry procedures has been associated with appropriate knowledge of the risks of developing diseases, making the dissemination of information a powerful tool of epidemiological surveillance. ${ }^{16}$
In a study on the preventive practices of elementary and high school students in the city of Rio de Janeiro, a significant lack of knowledge was found regarding important aspects of hepatitis transmission and prevention. ${ }^{15}$ Despite many seroprevalence studies, the literature shows a scarcity of research on general information about the etiology, transmission, and prevention of viral hepatitis. This study aims at assessing the knowledge of elementary school teachers on prevention of viral hepatitis infections.

\section{Material and Methods}

A cross-sectional pilot study was conducted from August to November, 1999, in three state capital cities of different areas (north, northeast and southeast) of Brazil, to assess cultural differences regarding knowledge on VH transmission and prevention. The data collection instrument used was an anonymous questionnaire with open questions. In addition to social and demographic characteristics (age, sex, and neighborhood) of the subjects, questions on transmission and practices for prevention of hepatitis were included. Subjects were elementary school teachers registered at pedagogy courses in the cities of Natal (northeast), Rio de Janeiro (southeast), and Belém (north). Teachers were chosen from randomly selected public schools. In all three cities, teachers who were present in days selected at random by the researcher (Belém) or scheduled for an interview by school authorities were interviewed. The application of the instrument lasted 30 minutes on average. Written informed consent was obtained from each participant prior to the interview. ${ }^{17, *}$

Data were tabulated and analyzed using EPIINFO 6.04; open answers were classified according to semantic content. ${ }^{18}$ The frequencies of information categories on transmission and preventive practices were interpreted according to the degree of knowledge on viral hepatitis. The unit of analysis of the frequencies referred to the answers for each category, since the questions allowed the identification of more than one answer for each subject in each item. Comparisons of the answer frequencies among cities was assessed with the chi-square test. The contents of categories of transmission and preventive practices are defined in Table I.

\footnotetext{
* This study met the requirements of the National Council of Health Deliberation $n^{\circ} 196 / 96$, and was approved by the Ethical Committee in Human Research of the Núcleo de Estudos de Saúde Coletiva of the Federal University of Rio de Janeiro (Brazil, 1998).
}

salud pública de méxico / vol.45, no.4, julio-agosto de 2003 
Knowledge of the subjects in relation to the correct answers to the questions was assessed using quantitative values assigned to "right" or "wrong" scores for each answer. Five items were considered for analyzing answers: a "right" score was assigned to correct information on transmission through food-and water, blood, sexual intercourse, vertical, and person to person. For prevention, a "right" score was assigned to correct information on transmission regarding access to quality drinking water and food, blood transfusions, safe sex practices, immunization, and personal and environmental care (e.g., avoiding contact with feces). Results from this pilot study, though not allowing direct inferences on the whole population, are very valuable for designing further studies including other regions and groups.

\section{Results}

The study sample was composed of 360 subjects ( 334 females and 26 males); 81 (22.5\%) were from Belém, 123 (34.2\%) from Natal, and 156 (43.3\%) from Rio de Janeiro. Ages varied from 18 to 58 years, with a mean of 32.5 years, a median of 31, and a mode of 21 years. The age distribution of the sample in the three cities was similar for Rio de Janeiro and Natal. In Belém, although the age limits are similar, the mean and medium ages were higher than in the other two cities, and the mode was almost two (1.8) times larger.
For the global sample (360 subjects) in the three cities a total of 837 answers were obtained for the transmission category and 771 for the prevention category. The results of questionnaire responses are shown in Table II.

The "food-and waterborne" item was the most frequently referred to (around $40 \%$ ), in the transmission category, followed by: bloodborne (15.5\%), uninformed $(10.8 \%)$ and inadequate knowledge with the same percentage values as the possible causes of hepatic disease $(8.7 \%)$. Sexual transmission was in the last place with $7.3 \%$ (table II).

For the prevention categories, the "food- and waterborne" item was predominant (39.9\%), followed by the "general aspects of prevention" (13.2\%) and "others/not informed" (10.4\%) items. "Immunization" came next with $9.5 \%$ of the references, followed by "relevance of blood and health services quality" with $7.8 \%$. "Sexual prevention" came in sixth place with $4.5 \%$ (Table II).

The score of correct answers regarding transmission mechanisms in the 360 subjects varied from zero to $80 \% ; 35.3 \%(n=127)$ of the subjects scored only $20 \%$; $27.8 \%(n=100)$ reached $40 \%$, and $9.4 \%(n=34)$ scored $60 \%$ (Table III). Ninety-six (26.7\%) had no correct answers and only three $(0.8 \%)$ had $80 \%$ of correct answers, while no one attained a score of $100 \%$. The percentage of correct answers on prevention practices in the 360 subjects also varied from zero to $80 \%: 33.6 \%(n=121)$

Table I

\section{Contents of the transmission and PReVention Categories}

Content

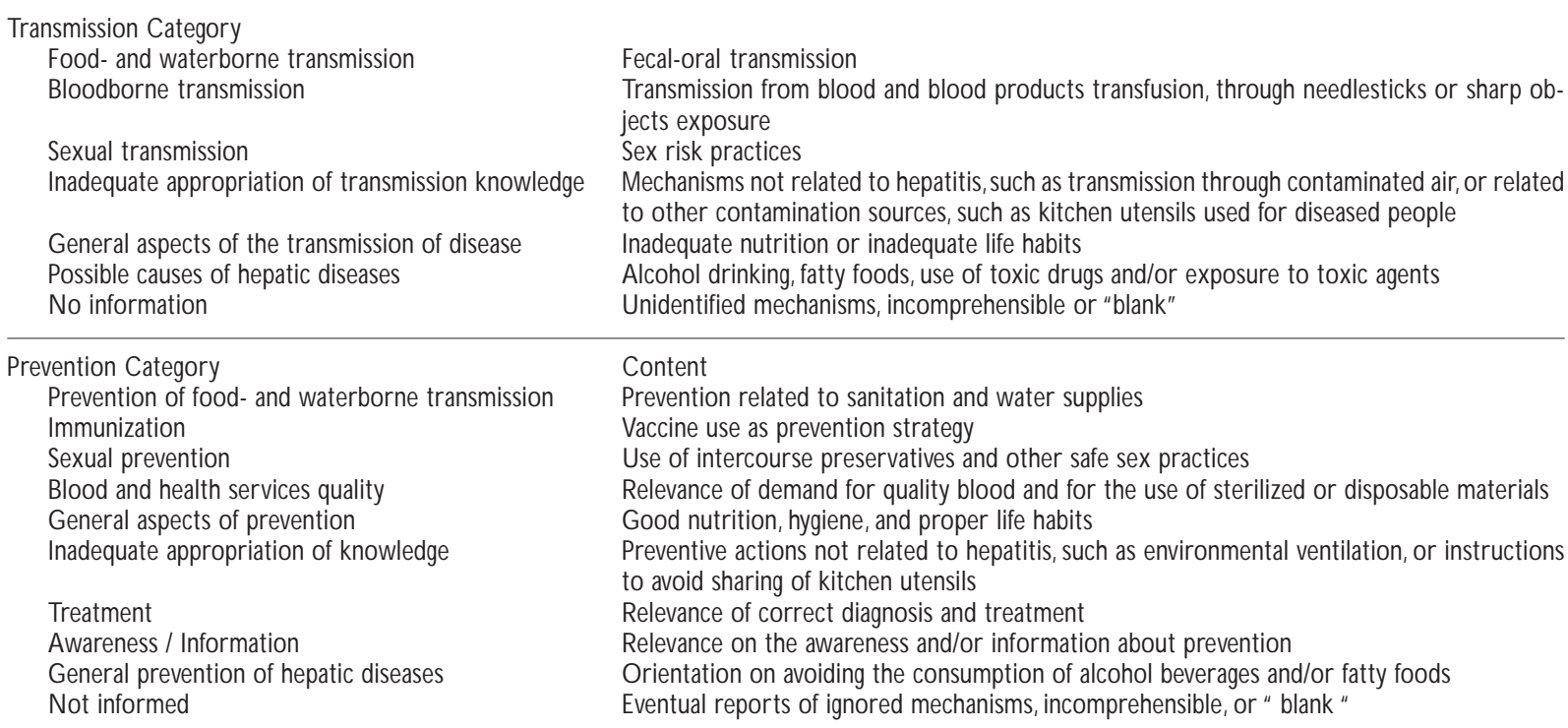


Table II

Distribution of transmission and preVention Categories according to the City, BraZiL, 1999

Transmission catego ries/city

\begin{tabular}{|c|c|c|c|c|c|c|c|c|c|c|c|}
\hline Food and waterborne transmission & 88 & 38.9 & 84 & 33.5 & 165 & 45.8 & 337 & 40.3 & 9.63 & 2 & 0.008 \\
\hline Bloodborne transmission & 22 & 9.7 & 41 & 16.3 & 67 & 18.6 & 130 & 15.5 & 8.51 & 2 & 0.014 \\
\hline Sexual transmission & 15 & 6.6 & 16 & 6.4 & 30 & 8.3 & 61 & 7.3 & 1.03 & 2 & 0.596 \\
\hline Inadequate appropriation & 23 & 10.2 & 18 & 7.2 & 38 & 10.6 & 79 & 9.4 & 2.18 & 2 & 0.336 \\
\hline General aspects of the transmission of diseases & 24 & 10.6 & 22 & 8.8 & 21 & 5.8 & 67 & 8.0 & 4.6 & 2 & 0.1 \\
\hline Possible causes of hepatic diseases & 36 & 15.9 & 20 & 8 & 17 & 4.7 & 73 & 8.7 & 22.2 & 2 & $<0.0001$ \\
\hline Not informed & 18 & 8 & 50 & 19.9 & 22 & 6.1 & 90 & 10.8 & 31.9 & 2 & $<0.0001$ \\
\hline Total & 226 & 100 & 251 & 100 & 360 & 100 & 837 & 100 & & & \\
\hline
\end{tabular}

Prevention categories/city

\begin{tabular}{|c|c|c|c|c|c|c|c|c|c|c|c|}
\hline Prevention of food and waterborne transmission & 91 & 43.3 & 78 & 33.9 & 139 & 42 & 308 & 39.9 & 5.07 & 2 & 0.079 \\
\hline Immunization & 22 & 10.5 & 20 & 8.7 & 31 & 9.4 & 73 & 9.5 & 0.41 & 2 & 0.813 \\
\hline Sexual prevention & 10 & 4.8 & 9 & 3.9 & 16 & 4.8 & 35 & 4.5 & 0.3 & 2 & 0.861 \\
\hline Blood and health services quality & 9 & 4.3 & 16 & 7 & 35 & 10.6 & 60 & 7.8 & 7.39 & 2 & 0.024 \\
\hline General aspects of prevention & 27 & 12.9 & 33 & 14.3 & 42 & 12.7 & 102 & 13.2 & 0.36 & 2 & 0.835 \\
\hline Inadequate appropriation of knowledge & 11 & 5.2 & 9 & 3.9 & 15 & 4.5 & 35 & 4.5 & 0.44 & 2 & 0.8 \\
\hline Treatment & 8 & 3.8 & 11 & 4.8 & 7 & 2.1 & 26 & 3.4 & 3.13 & 2 & 0.208 \\
\hline Awareness/information & 5 & 2.4 & 6 & 2.6 & 18 & 5.4 & 29 & 3.8 & 4.52 & 2 & 0.104 \\
\hline General prevention of hepatic diseases & 12 & 5.7 & 8 & 3.5 & 3 & 0.9 & 23 & 3.0 & 10.54 & 2 & 0.005 \\
\hline N ot informed & 15 & 7.1 & 40 & 17.4 & 25 & 7.6 & 80 & 10.4 & 17.37 & 2 & 0.0002 \\
\hline Total & 210 & 100 & 230 & 100 & 331 & 100 & 771 & 100 & & & \\
\hline
\end{tabular}

Table III

Distribution of the Percentile of SucCesses ACCording to the City, Brazil, 1999

Cities

Parameters

Categories of transmission

\begin{tabular}{lrrrrrrrrrrr}
$0 \%$ & 20 & 24.7 & 55 & 44.7 & 21 & 13.5 & 96 & 26.7 & 34.56 & 2 & $<0.0001$ \\
\hline $20 \%$ & 32 & 39.5 & 37 & 30.1 & 58 & 37.2 & 127 & 35.3 & 2.34 & 2 & 0.31 \\
\hline $40 \%$ & 23 & 28.4 & 21 & 17.1 & 56 & 35.9 & 100 & 27.8 & 12.17 & 2 & 0.002 \\
\hline $50 \%$ & 6 & 7.4 & 10 & 8.1 & 18 & 11.5 & 34 & 9.4 & 1.44 & 2 & 0.486 \\
\hline $80 \%$ & 0 & 0 & 0 & 0 & 3 & 1.9 & 3 & 0.8 & - & - & - \\
\hline $100 \%$ & 0 & 0 & 0 & 0 & 0 & 0 & 0 & 0 & - & - & - \\
\hline Total & 81 & 100 & 123 & 100 & 156 & 100 & 360 & 100 & &
\end{tabular}

Modes of prevention

\begin{tabular}{lrrrrrrrrrcc}
$0 \%$ & 27 & 33.3 & 71 & 57.7 & 40 & 25.6 & 138 & 38.3 & 31.05 & 2 & $<0.0001$ \\
\hline $20 \%$ & 26 & 32.1 & 30 & 24.4 & 65 & 41.7 & 121 & 33.6 & 9.31 & 2 & 0.009 \\
\hline $40 \%$ & 21 & 25.9 & 18 & 14.6 & 41 & 26.3 & 80 & 22.2 & 6.23 & 2 & 0.044 \\
\hline $60 \%$ & 7 & 8.6 & 3 & 2.4 & 8 & 5.1 & 18 & 5 & 3.97 & 2 & 0.137 \\
\hline $80 \%$ & 0 & 0 & 1 & 0.8 & 2 & 1.3 & 3 & 0.8 & - & - & - \\
\hline $100 \%$ & 0 & 0 & 0 & 0 & 0 & 0 & 0 & 0 & - & - & - \\
\hline Total & 81 & 100 & 123 & 100 & 156 & 100 & 360 & 100 & &
\end{tabular}

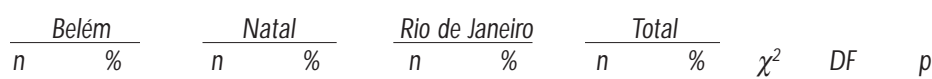


of subjects had only $20 \% ; 22.2 \%$ ( $n=80)$ scored $40 \%$; and $5 \%(n=18)$ reached $60 \%$. One hundred thirty eight subjects $(38.3 \%)$ had no correct answers, three $(0.8 \%)$ scored $80 \%$, and no one attained a score of $100 \%$.

Data were stratified by city to detect possible differences in data collection. Table II shows the distribution in Belém, Natal, and Rio de Janeiro, of contents on the transmission of viral hepatitis according to the categories shown in Table I. The "food-and waterborne" item was the most frequently mentioned $(38.9 \%)$ in Belém, followed by "possible causes of hepatic disea$\mathrm{se}^{\prime \prime}(15.9 \%)$, and "general aspects of the transmission of diseases" (10.6\%) items. In Natal, "food- and waterborne" showed a value of $33.5 \%$, "bloodborne" $16.3 \%$, and "general aspects of transmission of diseases" $8.8 \%$. In Rio de Janeiro, the "food- and waterborne" item reached a percentage of $45.8 \%$, followed by "bloodborne" with $18.6 \%$, and "inadequate knowledge" with $10.6 \%$.

The distribution of the categories concerning the practices of prevention of viral hepatitis in Belém, Natal, and Rio de Janeiro is shown in Table II. In Belém, the "food- and waterborne" item reached $43.3 \%$, followed by "general aspects of prevention" (12.9\%), and "immunization" (10.5\%). In Natal, the "food-and waterborne" item obtained 33.9\% of the answers, "general aspects of the prevention" $14.3 \%$, and "immunization" 8.7\%. In Rio de Janeiro, the following results were observed: "food-and waterborne" category ( $42 \%)$, "general aspects of prevention" (12.7\%), and "blood and health services quality" (10.6\%) (Table II).

Stratification of the number of correct answers by city showed that in relation to knowledge on transmission and means of prevention, the variation of the percentage of correct answers was between 0 and 80\%. The percentile distribution of correct answers by city is shown in Table III.

\section{Discussion}

Four discrepancies in answers of subjects were significant: the smaller percentage of references to the "foodand waterborne" transmission item in Natal (33.9\%) in relation to Belém $(43.3 \%)$, and Rio de Janeiro (42\%); the low percentage of references to "bloodborne prevention" in Belém (4.3\%) as compared with Rio (10.6\%) and Natal $(7 \%)$; the reduced reference to "general aspects of prevention of diseases" in Rio de Janeiro (0.9\%) relative to Belém (5.7\%) and Natal (3.5\%); and the "relevant misinformation or abstinence" in Natal (17.4\% against 7.6\% in Rio de Janeiro, and 7.1\% in Belém).

The "food-and waterborne" transmission and the "prevention through sanitation and drinking water supply" items seemed to be better known than the other items, as shown by the $40 \%$ of references to these items. However, some differences were observed among cities. The water component of this category was referred to significantly more often in Rio than in other cities $\left(\chi^{2}=9.63, p=0.008\right)$. Moreover, in relation to the prevention category, the sanitation component was not mentioned at all in Natal. It is interesting, however, to observe that in terms of drinking water supply and sewerage, $85.1 \%$ of the population in Rio de Janeiro have access to water and $85.1 \%$ have sewerage systems, while in Natal $77.7 \%$ have access to drinking water and 42.4 have sewerage systems) $)^{19}$. Study subjects, mainly those of Natal, seemed unable to fully recognize the relevance of this deficiency of urban infrastructure and/or they did not relate it to the acquisition or prevention of $\mathrm{VH}$.

Although $15.5 \%$ of study subjects referred to bloodborne transmission, they mentioned the control of quality of blood and health services less often (7.8\%). In Rio de Janeiro, blood was mentioned more frequently than in the other cities, the difference for Belém being statistically significant $\left(\chi^{2}=8.51\right.$ and $\left.p=0.014\right)$, possibly linked to the broader diffusion of information and $\mathrm{pu}-$ blic impact of contamination of blood with HIV in the 1980s, in Rio de Janeiro.

Desaggregating the bloodborne item of transmission in its several components, it was observed that the component "use of injected drugs" was only mentioned in $0.2 \%$ of the answers and when reference to prevention related to the use of syringes was made it was commonly linked to dental and medical practices. Remarkably, only in Natal reference was made to this important transmission vehicle.

Although discrepancy between information concerning the modes of transmission and recommendations on prevention has been observed in several occasions, the contrast in the blood category is noteworthy. If reference to the transfusion transmission could suggest people's indignation concerning this source of contamination, the reminder in smaller scale in respect to prevention could reflect detachment from the problem, seeing the control of the quality of blood as a government action not susceptible of modifications through the participation of the civil society.

Lack of knowledge in the role of sexual transmission was remarkable. Only in $7.3 \%$ of the answers was sex referred to as a way of transmission and even less often $(4.5 \%)$ was it mentioned regarding prevention. Although sexual transmission was mentioned more frequently in Rio de Janeiro (8.3\%) than in the other cities $(6.6 \%$ in Belém and $6.4 \%$ in Natal), this difference was not significant $\left(\chi^{2}=1.03\right.$ and $\left.p=0.596\right)$. This re- 
flects scarce knowledge, probably because this topic has received little media coverage.

The appropriation of knowledge was shown to be inadequate in relation to transmission $(9.4 \%)$ and to prevention $(4.5 \%)$. In this category, it was found that there is great concern about the use of utensils, such as dishes, glasses, and silverware used by diseased people. It was also mentioned, however infrequently, that kissing should be avoided to prevent viral hepatitis transmission. The belief that the use of utensils contaminated by infected persons, especially those that come into contact with the mouth, urine, and feces, is largely diffused in our society. This may have a common origin in the impregnation of the collective imaginary with information that some diseases, such as tuberculosis, can be transmitted in this way. Another contributing factor could be the popularization, in the media, of mistaken interpretations of research results about contamination with fecal coliforms of bar and restaurant utensils, which usually results from use of contaminated water and not from being handled by diseased persons. In the category denominated "general aspects of the transmission of diseases", food, inadequate lifestyle and insufficient environmental airing were mentioned as ways facilitating transmission $(8.0 \%)$ and as prevention methods $(13.2 \%)$. Unlike findings for other items, the general aspects of prevention were mentioned more often than transmission. Among the cities, it was observed that this category was mentioned least often in Rio de Janeiro, compared to the other cities $\left(\chi^{2}=4.6\right.$ and $\left.p=0.1\right)$. For the prevention category, the component of environmental airing seemed to pervade the answers; a curious fact considering that viral hepatitis infections are not transmitted through the air and, therefore, cannot be prevented in this way. The quality of life component was mentioned by $6.7 \%$ of the subjects as a preventive measure; it denotes the value that has been attributed to life conditions and reflects its relationship with health.

Becoming infected with a disease was frequently associated with behavior lacking prevention measures. Although the caloric or qualitative content of foods does not interfere directly in the transmission or prevention of the viral hepatitis, medical recommendations about the type and amount of fat intake allowances are given to the patients. However, these recommendations end up constituting a collection of self-imposed limitations by healthy people. On the other hand, irresponsible lifestyles and inadequate personal hygiene are regarded as causing disease.

Vaccination was mentioned in $9.6 \%$ of the answers, although most of the time it seems to refer to a general knowledge on the importance of this practice in disease prevention. However statistically insignificant, the percentage of references on prevention by immunization was higher in Belém (10.5\%) than in Rio $(9.4 \%)$ and Natal $(8.7 \%)$. This may be due to the proximity to the Delta (Western Amazon) area of high endemicity for hepatitis B, where there is ample information on the existence of vaccines against viral hepatitis.

Relative misinformation about transmission was observed in $10.8 \%$ and about prevention in $10.4 \%$. This was acknowledged by study subjects themselves, who then demanded educational campaigns. Natal showed the highest misinformation percentage, being significantly higher than in the other cities in relation to transmission $\left(\chi^{2}=31.9\right.$ and $\left.p<0.0001\right)$ and to prevention $\left(\chi^{2}=17.37\right.$ and $\left.p=0.0002\right)$. An interpretation for this could be that the popularization of information through the media is larger in Rio de Janeiro than in the other capitals. Moreover, there are no non-governmental organizations contributing to disseminate social concern on the problem of VH in Natal and Belém ${ }^{20}$.

Alcoholic beverages, fat, medicines, and toxic substances were also referred to as ways of acquiring hepatitis and, in consequence, avoiding them was referred to as a form of prevention. In Belém, this category (especially drinking) was mentioned more often than in the other cities $\left(\chi^{2}=22.2\right.$ and $\left.p<0.0001\right)$ as a cause of hepatitis. The same finding was observed for the prevention categories concerning this item $\left(\chi^{2}=10.54\right.$ and $p=0.005$ ).

Only $10.2 \%$ of the 360 subjects scored $60 \%$ or $80 \%$ correct answers on transmission, as did $5.8 \%$ for the prevention category. These figures confirm previous findings on knowledge concerning these aspects. They also confirm the observed knowledge deficiencies and the need for greater dissemination of information on this important topics. Natal presented the higher percentage of blank or null answers, both for information on the routes of transmission $(44.7 \%)\left(\chi^{2}=34.56\right.$ and $p<0.0001)$ and modes of prevention $(57.7 \%)\left(\chi^{2}=31.05\right.$ and $p<0.0001)$. As for the 20,40 , or $60 \%$ scores of the two questions, Natal also showed consistently lower percentages when compared with the other cities, although these differences were significant only for $40 \%$ scores on the question about routes of transmission $\left(\chi^{2}=12.17\right.$ and $\left.p<0.002\right)$ and for $20 \%$ scores on the question about prevention $\left(\chi^{2}=9.31\right.$ and $\left.p<0.009\right)$.

Teachers' knowledge seems to be inadequate and inefficient for attaining effective prevention practices against viral hepatitis. Interviewees' self acknowledgement of the need for information was evident, pointing to the need for investment in actions to disseminate 
appropriate knowledge on viral hepatitis and collaboration with schools to prepare teachers to promote prevention of $\mathrm{VH}$.

Information on sexual transmission and intravenous drug use transmission is especially important, for teachers work directly with youths and are able to disseminate information. Beliefs leading to excessive concern with patients' utensils reveal inadequate appropriation of knowledge on fecal-oral, blood, and sexual transmission.

The following findings merit in-depth research using focal studies: the scarce knowledge of the existence of vaccines against hepatitis A and B; the failure to recognize intravenous drug use as transmission vehicles in Rio de Janeiro and in Belém; and the reduced understanding concerning the relevance of the quality of water and good sanitary conditions, especially in Natal and Belém.

Studies and interventions are recommended to make possible the diffusion of information on viral hepatitis, inducing positive changes in the appropriation of this knowledge.

\section{References}

1. Ministério da Saúde. Fundação N acional de Saúde. CEN EPI [Editorial]. Boletim Epidemiológico 0 ut. 1996;।(10):2.

2. Clemens $S A$, da Fonseca JC, A zevedo T, C avalcanti A, SilveiraTR, $C$ astilho $M C$ et al. Hepatitis $A$ and hepatitis $B$ seroprevalence in 4 centers in Brazil. Rev Soc Bras M ed Trop 2000;33(1):1-10.

3. G aze R. Hepatites Virais:Alfabeto Submerso. D issertação de Mestrado. N úcleo de Estudos de Saúde Coletiva/U FRJ. Rio de Janeiro, 1999. 4. Miranda LVG , Passos ADC , Figueiredo JFC, G aspar AMC, Yoshida CF. Prevalência de anticorpos contra hepatite $A$ em população submetida à coleta de sangue em unidades de saúde. In: IV Congresso Brasileiro de Epidemiologia. Livro de Resumos. 1998; Rio de Janeiro 235 (Poster 0306). 5.Treitinger A, Spada C, Ferreira LA, N eto MS, Reis M, Verdi JC et al. Hepatitis B and hepatitis $C$ prevalence among blood donors and HIV-1 infected patients in Florianópolis - Brazil. Braz J Infect Dis 2000;4(4):

192-6.

6. W orld Health 0 rganization. Expanded Programme on Immunization: Hepatitis B vaccine - making glo bal progress. G inebra:W HO 1996.

7. Bensabath G, Hadler SC, Soares MCP, Fields H, Maynard JE. Características serológicas y epidemiológicas de la hepatitis vírica aguda en la cuenca amazónica del Brasil. Bol Oficina Sanit Panam 1987;103(4):351-362.

8. $O$ liveira LHS, Silva IR, X avier BLS, C avalcanti SMB. Hepatitis B infection among patients attending a sexually transmitted diseases clinic in Rio de Janeiro, Brazil. Mem Inst 0 swaldo Cruz 2001;96(5):635-640. 9. PaulaVS, Arruda ME,Vitral CL, Gaspar AMC. Seroprevalence of viral hepatitis in riverine communities from the W estern Region of the Brazilian A mazon Basin. Mem Inst 0 swaldo C ruz 2001;96(8):1123-1128. 10. Centers for D isease Control and Prevention. Epidemiology and Prevention of Viral Hepatitis A to E:An Overview. Hepatitis Branch Homepage,Atlanta. Disponible en: http:// www.cdc.gov/ ncidod/ diseases/ hepatitis/ hepatitis.htm, U pdate 19/05/99. 1999.

11. W orld Health 0 rganization. Hepatitis C. Fact Sheet $\mathrm{N} \cong .164$.

D isponible en: http://www.who.int/inf-fs/en/fact164.html, 0 ct., 2000. Consultada el 22 de mayo de 2001.

12. Sociedade Brasileira de Hepatologia. Epidemiologia da Infecção pelo vírus da hepatite $C$ no Brasil. Dispnible en: http://

www.sbhepatologia.org.br/, 1999 .

13. 0 liveira ML, Bastos FI,Telles PR, Yoshida CF, Schatzmayr HG, Paetzold $U$ et al. Prevalence and risk factors for HBV, HCV and HDV infections among injecting drug users from Rio de Janeiro, Brazil. Braz J Med Biol Res 1999;32(9):1107-14.

14. Lemon SM. Inactivated hepatitis A virus vaccines. [Editorial] Hepatology 1992;15(6):1194-7, 1992.

15. G aze R, Affonso KC,A rany C, C arvalho DM, Tura LFR. Informação e percepção de risco sobre hepatites virais: um estudo com escolares. Cadernos Saúde Coletiva 1997;5(2):57-70.

16. Fischmann A.Vigilância Epidemiológica. En: Rouquayrol MZ, ed. Epidemiologia \& Saúde. 4a. ed. Rio de Janeiro: MED SI, 1993;421-441, 1993.

17. Conselho N acional de Saúde. Brasil. Resolução N 0.196 de 10 de outubro de 1996: "A prova diretrizes e normas regulamentadoras de pesquisas envolvendo seres humanos". Cadernos de Ética em Pesquisa 1998;1(1):34-46

18. Bardin L.A Aálise de conteúdo. Lisboa: Edições 70, 1979.

19. Ministério da Saúde. DATASUS. Indicadores e Dados Básicos - Brasil1998. IBGE - PN AD. Disponible en: http://www.datasus.gov.br. 28/11/ 2000.

20.Varaldo C. Convivendo com a hepatite C: Experiências e informações de um portador do vírus. S/ Editora, 2000:268. 